\title{
Salinity Tolerance and Leaf Water Use Efficiency in Citrus
}

\author{
James P. Syvertsen ${ }^{1}$ and Juan C. Melgar \\ Horticultural Sciences Department, University of Florida, IFAS, Citrus Research and Education \\ Center, 700 Experiment Station Road, Lake Alfred, FL 33850 \\ Francisco García-Sánchez \\ CEBAS, CSIC, Campus Universitario de Espinardo, Espinardo, 30100 Murcia, Spain
}

\begin{abstract}
Additional Index words. elevated $\mathrm{CO}_{2}, \mathrm{Cl}^{-}$, rootstock, shade, soil type, transpiration
Abstract. In three separate experiments, the growth and water use of salinized citrus rootstock seedlings and grafted trees were modified using different growth substrates, elevated $\mathrm{CO}_{2}$, or $50 \%$ shade screen under field conditions. By reanalyzing previously published data, we tested the hypothesis that salinity tolerance in citrus can be characterized as the ability to maintain low levels of leaf $\mathrm{Cl}^{-}$accumulation through high plant growth and high water use efficiency (WUE) under saline conditions. Well-irrigated salinized seedlings of the relatively salt-sensitive Carrizo citrange [Carr (Citrus sinensis $\times$ Poncirus trifoliata)] were grown in sand, clay, or a peat-based soilless media. Salinity stress reduced plant growth and water use. Leaf $\mathrm{Cl}^{-}$concentration was negatively related to plant growth, but leaf $\mathrm{Cl}^{-}$ increased with transpiration rate in low-saline treatments. In a second experiment using salinized seedlings of the relatively salt-tolerant Cleopatra mandarin [Cleo (Citrus reticulata)] grown along with Carr seedlings with or without elevated $\mathrm{CO}_{2}$, leaf $\mathrm{Cl}^{-}$was negatively related to growth and to shoot/root dry weight ratio, but was positively related to water use such that leaf $\mathrm{Cl}^{-}$was negatively related to leaf WUE. In a third experiment using salinized 2-year-old 'Valencia' orange ( $C$. sinensis) trees grafted on Cleo or Carr rootstocks and grown with or without shadecloth, leaf $\mathrm{Cl}^{-}$ was positively related to leaf transpiration as both were higher in the spring than in the fall, regardless of rootstock or shade treatment. Overall, leaf $\mathrm{Cl}^{-}$was positively related to water use and was negatively related to leaf WUE. High growth, low water use, and consequently, high WUE of salinized citrus were related to low leaf $\mathrm{Cl}^{-}$. Such relationships can be used as indicators of salinity tolerance.
\end{abstract}

There is a wide range of plant growth and physiological responses to excessive salt ion accumulation and osmotic stress from high salinity (Yeo and Flowers, 1989). Due to the complexity of salt tolerance in crops (Flowers and Flowers, 2005) and trees (Levy and Syvertsen, 2004), attempts to improve the salt tolerance of plants have met with very limited success. Progress in improving salinity tolerance will come through an understanding of processes controlling the uptake and transport of $\mathrm{Na}^{+}$and $\mathrm{Cl}^{-}$in plants (Munns and James, 2003). In leaves of relatively salt-sensitive citrus (Maas, 1993), the accumulation of $\mathrm{Cl}^{-}$is considered to be a more important limitation on growth and physiological responses than $\mathrm{Na}^{+}$(Bañuls et al., 1997; Levy and Syvertsen, 2004; Lopez-Climent et al., 2008). Salt-induced defoliation, regulation of $\mathrm{Cl}^{-}$transporter genes, and other physiological responses in citrus have been correlated with foliar $\mathrm{Cl}^{-}$accumulation rather than with levels of $\mathrm{Na}^{+}$or osmotic stress (Brumós et al., 2009). Citrus trees are almost always grafted on rootstocks, which not only affects tree water relations and growth (Castle et al., 1993), but also the amount of $\mathrm{Cl}^{-}$and/or $\mathrm{Na}^{+}$accumulated in foliage under saline conditions (Maas, 1993). For example, the citrus rootstock Cleopatra mandarin is relatively a $\mathrm{Cl}^{-}$excluder, whereas Carrizo citrange is a $\mathrm{Cl}^{-}$accumulator but a Na+ excluder (Storey and Walker, 1999). Although such root characteristics tend to be consistent even

Received for publication 24 Nov. 2009. Accepted for publication 12 Jan. 2010. Part of the funding for this research came from the Ministerio de Educación y Ciencia (Gobierno de España), Project Plan Nacional AGL2007-65437-C0402/AGR, and from the University of Florida, IFAS, CREC

We thank Jill Dunlop for technical assistance.

${ }^{1}$ Corresponding author. E-mail: jmsn@ufl.edu. when rootstocks are grown as seedlings in a greenhouse, there are often confusing interpretations of the relative rankings of rootstock tolerance to salinity in the literature depending on variations in salinity treatment, duration, scion type, growth substrate, and whether growth or physiological responses were measured (Levy and Syvertsen, 2004). For example, salinityinduced reductions in citrus leaf gas exchange (García-Sánchez and Syvertsen, 2009) or chlorophyll fluorescence parameters (García-Sánchez and Syvertsen, 2006; Lopez-Climent et al., 2008) are not always good indicators of plant growth and leaf $\mathrm{Cl}^{-}$accumulation.

Citrus leaves can osmotically adjust to saline conditions such that the relative water content of leaves is maintained even under concomitant drought stress (Pérez-Pérez et al., 2007), and under well-watered saline conditions, osmotic adjustment often increases leaf turgor above that of non-salinized leaves (GarcíaSánchez and Syvertsen, 2006). Leaf $\mathrm{Cl}^{-}$concentration and, thus, relative salt tolerance has been linked to plant growth, water use (Castle and Krezdorn, 1975; Syvertsen et al., 1989), and transpiration (Moya et al., 1999, 2003). Because rapidly growing trees always use more water than slower-growing trees, leaves on rapidly growing trees would be exposed to relatively more $\mathrm{Cl}^{-}$in the transpiration stream than leaves on slower-growing trees (Syvertsen et al., 1989). Thus, at least part of the mechanism underlying high salt tolerance or the accumulation of relatively low leaf $\mathrm{Cl}^{-}$in some citrus rootstocks may be related to their low growth vigor, low water use, and/or a high shoot/root ratio (Moya et al., 2003).

Plant growth, net $\mathrm{CO}_{2}$ assimilation $\left(A_{\mathrm{C}}\right)$, and water use efficiency (WUE) of most crop plants can be increased when plants are grown in elevated $\mathrm{CO}_{2}\left(\mathrm{eCO}_{2}\right)$, but at the same time, 
leaf transpiration $\left(E_{1 \mathrm{f}}\right)$ and plant water use usually are decreased (Bowes, 1991; Chen and Lenz, 1997). Therefore, growing plants at $\mathrm{eCO}_{2}$ offers a mechanism to separate plant growth from water use, two processes that are normally tightly coupled. Even salt-stressed plants generally grow more at $\mathrm{eCO}_{2}$ than at ambient levels of $\mathrm{CO}_{2}$ (Ball and Munns, 1992). If water use and salt uptake are indeed linked (Moya et al., 2003), then increasing WUE in $\mathrm{eCO}_{2}$ should result in reduced rates of salt accumulation in the leaves. Elevated $\mathrm{CO}_{2}$ increased growth and decreased leaf $\mathrm{Cl}^{-}$and $\mathrm{Na}^{+}$in the salt-sensitive Carr seedlings, but tended to increase both ions in leaves of the more salttolerant Cleo (García-Sánchez and Syvertsen, 2006).

The effects of salinity stress can be worse in full sun than in shade in evergreen species (Tattini et al., 2006). In citrus, 50\% shade screens reduced excessively high leaf temperatures and leaf-to-air vapor pressure differences (VPD) at midday such that leaf $A_{\mathrm{C}}$ and WUE were increased above that of unshaded leaves (Syvertsen et al., 2003). Although $E_{1 \mathrm{f}}$ and whole plant water use are changed little by shade (Jifon and Syvertsen, 2003a, 2003b), shade-induced increases in WUE (GarcíaSánchez et al., 2006) may be related to differences in leaf $\mathrm{Cl}^{-}$of salinized 'Valencia' orange trees as determined by rootstocks with different abilities to exclude $\mathrm{Cl}^{-}$. We used the modified growth and water use of salinized citrus rootstock seedlings (García-Sánchez and Syvertsen, 2006, 2009) and grafted trees (García-Sánchez et al., 2006) to test the hypothesis that modified growth, water use, and WUE of salinized citrus reflects salinity tolerance as determined by leaf $\mathrm{Cl}^{-}$concentration. Such responses may yield insights into mechanisms of salinity tolerance, including processes controlling the uptake and transport of $\mathrm{Cl}^{-}$in citrus, and may provide clear indices of salinity tolerance.

\section{Materials and Methods}

All experiments were carried out at the University of Florida/Institute of Food and Agricultural Sciences Citrus Research and Education Center, Lake Alfred (lat. $28^{\circ} 9^{\prime} \mathrm{N}$, long. $81^{\circ} 73^{\prime} \mathrm{W}$; elevation $51 \mathrm{~m}$ ). Salinity stress was imposed using $50 \mathrm{~mm} \mathrm{Cl}^{-}$, a level known to induce physiological responses and reductions in growth within 8 weeks without visible leaf injury or defoliation in well-irrigated citrus species growing in a greenhouse (García-Sánchez and Syvertsen, 2006, 2009) or in the field (García-Sánchez et al., 2006; Levy and Syvertsen, 2004).

Expt. 1: Salinity and substrate TyPe. To determine the effect of substrate type on root salinity levels, uniform 1-monthold Carr seedlings were transplanted into $0.15-\mathrm{L}$ containers filled with autoclaved native Candler sand soil, Floridana clay soil, or the commercial soilless mixture of peat/perlite/vermic- ulite at $82.5 \% / 12.5 \% / 0.5 \%$ by volume (Pro-Mix BX; Premier Horticulture, Red Hill, PA) (García-Sánchez and Syvertsen, 2009). Candler soil is a well-drained typic quartzipsamment that is about $97 \%$ sand with $1 \%$ organic matter, whereas Floridana clay soil is a poorly drained loamy Argiaquoll that is $30 \%$ clay, $54 \%$ sand, and $1 \%$ organic matter (Table 1 ). Seedlings were grown in a greenhouse under natural photoperiods during the late summer when maximum photosynthetically active radiation $(P A R)$ at plant level was about 1200 $\mathrm{mmol} \cdot \mathrm{m}^{-2} \cdot \mathrm{s}^{-1}(\mathrm{LI}-170$; LICOR, Lincoln, NE). The average day/ night temperature was $36 / 21{ }^{\circ} \mathrm{C}$ and relative humidity varied diurnally from $40 \%$ to $100 \%$.

Plants were irrigated every other day with a dilute solution of a complete fertilizer $(8 \mathrm{~N}-0.7 \mathrm{P}-6.6 \mathrm{~K})$ plus $6 \%$ iron chelate in a sufficient volume to leach from the bottom of all pots. Plants received about $21 \mathrm{mg}$ of $\mathrm{N}$ per week. Two months after transplanting, $0 \mathrm{~mm}$ (control) or $50 \mathrm{~mm} \mathrm{NaCl}$ (salt) was added to the nutrient solution. To avoid an osmotic shock, salinity was increased in increments of $10 \mathrm{~mm} \mathrm{NaCl}$ per day until $50 \mathrm{~mm}$ $\mathrm{NaCl}$ was achieved. There were six replicate plants in each substrate and salinity treatment. After 9 weeks of treatment, salinized clay soil had a higher total electrical conductivity (EC) and $\mathrm{Cl}^{-}$concentration in the leaching fraction than the other substrates (Table 1). Leachates from the non-saline treatments had low EC and $\mathrm{Cl}^{-}$concentrations that were unaffected by substrate.

All leaf measurements used fully expanded mature leaves from the mid-stem area on each 5-month-old seedling. Net gas exchange (including $A_{\mathrm{C}}, E_{\mathrm{lf}}$, and WUE) of mature leaves was determined with a LI-COR portable photosynthesis system (LI6200) using a well-stirred 0.25-L cuvette. All measurements were made in the morning from about 0800 to 1100 HR to avoid high afternoon temperatures and low humidity, which can cause midday depression of net gas exchange (Hu et al., 2009; Jifon and Syvertsen, 2003a). All measurements were made under saturating $P A R\left(\geq 800 \mu \mathrm{mol} \cdot \mathrm{m}^{-2} \cdot \mathrm{s}^{-1}\right)$, leaf temperatures of $32 \pm$ $2{ }^{\circ} \mathrm{C}$, and VPD of $2.4 \pm 0.4 \mathrm{kPa}$ within the cuvette. Measurements were made on a single mature leaf on each of the six replicate plants in each substrate and salt treatment.

At the end of the experiment, whole plant transpiration $\left(E_{\mathrm{wp}}\right)$ was also measured gravimetrically by daily weight loss from each pot sealed in a plastic bag at the base of the stem, divided by the total leaf area at harvest, expressed in units of grams per square meter per hour. At harvest, plants were separated into leaves, stems, and roots, briefly rinsed in deionized water, and oven dried at $60{ }^{\circ} \mathrm{C}$ for at least $48 \mathrm{~h}$.

EXPT. 2: Salinity AND Elevated $\mathbf{C O}_{2}$. Uniform 2-month-old citrus rootstock seedlings of Cleo and Carr were transplanted into Candler sand and fertilized with a complete nutrient solution $(8 \mathrm{~N}-0.9 \mathrm{P}-6.6 \mathrm{~K}+\mathrm{Fe}-\mathrm{chelate})$, with or without additional

Table 1. (Expt. 1) Percentages of sand, silt, clay, and organic matter [OM (from García-Sánchez and Syvertsen, 2009)] along with mean (n = 6), electrical conductivity (EC), and $\mathrm{Cl}^{-}$concentration in the leaching fraction collected from salinized $(+\mathrm{S})$ and non-salinized $(-\mathrm{S}) \mathrm{Candler}$ sand, Floridana clay soil, and a soilless peat mix.

\begin{tabular}{lcccccccc}
\hline Substrate & Sand (\%) & Silt (\%) & Clay (\%) & OM (\%) & EC $-\mathrm{S}\left(\mathrm{dS} \cdot \mathrm{m}^{-1}\right)$ & $\mathrm{EC}+\mathrm{S}\left(\mathrm{dS} \cdot \mathrm{m}^{-1}\right)$ & $\mathrm{Cl}^{-}-\mathrm{S}(\mathrm{mM})$ & $\mathrm{Cl}^{-}+\mathrm{S}(\mathrm{mM})$ \\
\hline Candler sand & 97 & 1 & 1 & 1 & 2.4 & $10.0 \mathrm{~b}^{\mathrm{y}}$ & 2.3 & $82.2 \mathrm{~b}$ \\
Floridana clay & 54 & 15 & 30 & 1 & 2.3 & $12.0 \mathrm{a}$ & 2.5 & $102.7 \mathrm{a}$ \\
Soilless peat mix $^{\mathrm{z}}$ & - & - & - & 81 & 2.0 & $9.8 \mathrm{~b}$ & 2.0 & $82.6 \mathrm{~b}$
\end{tabular}

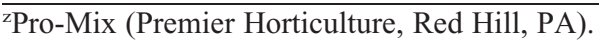

${ }^{\mathrm{y}}$ Means within a column followed by different lower case letter are significantly different via Duncan's multiple range test at $P<0.05$. 
Table 2. (Expt. 3) The effect of the shade treatment above 'Valencia' orange trees on midday $P A R$, leaf temperature ( $\left.T_{\mathrm{lf}}\right)$, and leaf-to-air vapor pressure difference (VPD) along with daylength (lat. $28^{\circ} 9^{\prime} \mathrm{N}$ ) on the measurement dates at the end of the spring and fall salinization period.

\begin{tabular}{llccccc}
\hline Date & Period & Treatment & $P A R\left(\mu \mathrm{mol} \cdot \mathrm{m}^{-2} \cdot \mathrm{s}^{-1}\right)$ & $T_{\text {lf }}\left({ }^{\circ} \mathrm{C}\right)$ & VPD $(\mathrm{kPa})$ & Day length $(\mathrm{h}: \mathrm{min})$ \\
\hline 22 June 2003 & Spring & Sun & 1884 & 37.5 & 3.53 & $13: 56$ \\
& & Shade & 773 & 34.6 & 2.65 \\
7 Nov. 2003 & Fall & Sun & 1302 & 34.7 & 3.03 & 10.57 \\
& & Shade & 614 & 32.3 & 2.38 \\
\hline
\end{tabular}

$50 \mathrm{~mm} \mathrm{NaCl}$, and were grown at ambient $\mathrm{CO}_{2}\left(360 \mu \mathrm{L} \cdot \mathrm{L}^{-1}\right)$ or $\mathrm{eCO}_{2}\left(700 \mu \mathrm{L} \cdot \mathrm{L}^{-1}\right)$ in controlled environment greenhouses for 8 weeks (García-Sánchez and Syvertsen, 2006). Net gas exchange was evaluated as above on a single mature leaf on each of the eight replicate plants in each rootstock, salt, and $\mathrm{CO}_{2}$ treatment. At the end of the experiment, $E_{\mathrm{wp}}$ was measured gravimetrically and plants were harvested as above.

Expt. 3: Salinity and shade. We determined physiological responses to shade and salinity of well-watered and fertilized 2-year-old 'Valencia' orange trees grafted on Cleo or Carr rootstocks throughout one growing season (García-Sánchez et al., 2006). Twenty uniform trees on each rootstock were grown outdoors in 5-L plastic containers filled with native Candler sand. Trees were watered three times per week with $1 \mathrm{~L}$ of water with soluble fertilizer $(9 \mathrm{~N}-0.9 \mathrm{P}-7.5 \mathrm{~K}), \mathrm{Ca}\left(\mathrm{NO}_{3}\right)_{2}$, and ironchelate $(6 \%)$ with an $\mathrm{N}$ concentration of $66 \mathrm{mg} \cdot \mathrm{L}^{-1}$. The $1-\mathrm{L}$ volume of nutrient solution was enough to achieve leaching from the bottom of all containers.

The shade treatment was conducted from April to Nov. 2003 by placing $50 \%$ shade screens (Aluminet-50; Polysack Plastic Industries, Nir Yitzhak, Israel) on top of 2.2-m-tall PVC frames constructed over the trees (García-Sánchez et al., 2006). Two salinity treatments, 0 and $50 \mathrm{~mm} \mathrm{Cl}^{-}\left[\mathrm{NaCl}\right.$ and $\left.\mathrm{CaCl}_{2}(3: 1)\right]$ added to the nutrient solutions, were evaluated on five trees on each rootstock in full sun or under the shade. The salinity treatment was begun at the same time as the shade treatment, but the salinity was applied during the two 9-week dry periods, 23 Apr. to 24 June and 18 Sept. to 21 Nov. At the beginning of each period, the salinity treatment was added in increasing increments of $15 \mathrm{mM} \mathrm{Cl}^{-}$per day during $2 \mathrm{~d}$ (consecutive) to avoid osmotic shock. On the third day, salinity was increased by $20 \mathrm{~mm} \mathrm{Cl}^{-}$to reach the final concentration of $50 \mathrm{~mm} \mathrm{Cl}^{-}$. Although the shade treatment was maintained during the intervening typical summer rainy period $(25$ June-17 Sept.), the previously salinized trees were irrigated only as necessary with the standard nutrient solution without salt.

Leaf gas exchange was measured as above on selected clear days near the end of each salinity period under ambient full sun or shade. Measurements were made on two mature leaves chosen from the mid-shoot area of each tree, giving 10 replicate leaves per treatment. Leaves measured at the end of the spring salinity period (22 June) were spring flush leaves about 3 months old and leaves at the end of the fall salinity period (7 Nov.) were summer flush leaves about 4 months old. Average measurement conditions are summarized in Table 2. At the end of the experiment, trees were harvested and dried as above.

Tissue $\mathbf{C L}^{-}$. In all three experiments, near the end of each salinity period, dried mature leaves and dried fibrous roots were ground to a powder. Tissue $\mathrm{Cl}^{-}$concentration, expressed in percentage dry weight (DW), was measured using a silver ion titration chloridometer (Haake Buchler, Sandle Brook, NJ) after the tissue had been extracted with $0.1 \mathrm{~N}$ solution of nitric acid and 10\% acetic acid. Titrations were calibrated against known chloride standards bracketing the range of $\mathrm{Cl}^{-}$in tissues. As an estimate of total $\mathrm{Cl}^{-}$accumulation, and leaf and root $\mathrm{Cl}^{-}$ contents (in milligrams) were calculated by multiplying tissue DW by their $\mathrm{Cl}^{-}$concentration.

DATA ANALYSIS. Data were analyzed using factorial analysis of variance (ANOVA; SAS version 9.1; SAS Institute, Cary, NC) and means were separated using Duncan's multiple range test at $P<0.05$. Within each of the three experiments, data were combined across treatments, and linear regression and Pearson's correlation coefficients were used to investigate relationships between selected variables.

\section{Results}

Expt. 1: Salinity and substrate type. Salinized Carr seedlings growing in Floridana clay soil had higher leaf $\mathrm{Cl}^{-}$ concentrations and grew less than seedlings in the other two substrates (García-Sánchez and Syvertsen, 2009; Fig. 1A). Across all substrates and salinity treatments, there was a negative relationship between leaf $\mathrm{Cl}^{-}$and total plant DW $(\mathrm{r}=$ $-0.85, P<0.001)$. In addition, there was a significant increase in leaf $\mathrm{Cl}^{-}$with increased $E_{\mathrm{wp}}$ rates across the low salinity

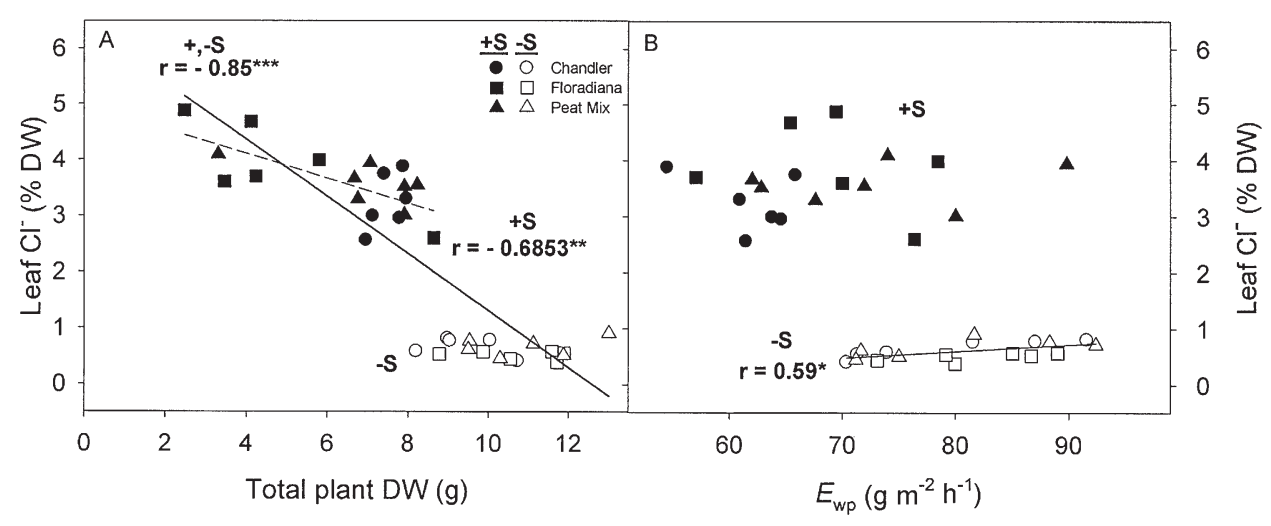

Fig. 1. (Expt. 1) Effects of growing Carrizo citrange seedlings in salinized [ $+\mathrm{S}$ (solid symbols)] or non-salinized [-S (open symbols)] Candler sand, Floridana clay soil, or a soilless peat mix on relationships between leaf $\mathrm{Cl}^{-}$ concentration and (A) total plant DW and (B) whole plant leaf transpiration $\left(E_{\mathrm{wp}}\right) ;+\mathrm{S}=$ dashed line, all data and $-\mathrm{S}=$ solid line; $* * * * *$, or $*=$ correlations coefficients that are significant at $P<0.001,0.01$, or 0.05 , respectively. 
treatments, but there was no relationship between leaf $\mathrm{Cl}^{-}$and $E_{\mathrm{wp}}$ in high salinity seedlings (Fig. 1B). Overall, larger plants, of course, used more water, as $E_{\mathrm{wp}}$ was correlated (r $=0.44, P<$ $0.01)$ to total plant DW. Leaf $\mathrm{Cl}^{-}$concentrations were correlated with leaf $\mathrm{Cl}^{-}$contents within low salinity treatments and overall salinity and substrate treatments (Fig. 2A). Root $\mathrm{Cl}^{-}$concentrations were similarly correlated with root $\mathrm{Cl}^{-}$contents regardless of substrate or salinity treatments (Fig. 2B).

Expt. 2: SAlinity AND ECO $\mathbf{O}_{2}$. Cleo seedlings were larger and had higher shoot/root DW ratio $(\mathrm{Sh} / \mathrm{Rt})$ than the same aged Carr seedlings regardless of $\mathrm{CO}_{2}$ level, and salinized Cleo seedlings had lower leaf $\mathrm{Cl}^{-}$concentrations than Carr seedlings (GarcíaSánchez and Syvertsen, 2006). Combining salinized data from both seedling types and both $\mathrm{CO}_{2}$ levels, leaf $\mathrm{Cl}^{-}$was negatively related to total plant DW $(\mathrm{r}=-0.56, P<0.01)$ as larger plants had lower leaf $\mathrm{Cl}^{-}$than smaller plants (Fig. 3A). Leaf $\mathrm{Cl}^{-}$also was negatively related to $\mathrm{Sh} / \mathrm{Rt}(\mathrm{r}=-0.71, P<0.001$; Fig. $3 \mathrm{~B})$. Across all $\mathrm{CO}_{2}$ and salinity treatments, leaf $\mathrm{Cl}^{-}$concentrations were again strongly correlated with leaf $\mathrm{Cl}^{-}$contents $(\mathrm{r}=0.65$, $P<0.001)$ and root $\mathrm{Cl}^{-}$concentrations were correlated with root $\mathrm{Cl}^{-}$contents $(\mathrm{r}=0.75, P<0.001$; data not shown).

Elevated $\mathrm{CO}_{2}$ increased $A_{\mathrm{C}}$ and decreased $E_{1 \mathrm{f}}$ in both species (García-Sánchez and Syvertsen, 2006). Overall, leaf $\mathrm{Cl}^{-}$increased with $E_{\mathrm{wp}}$ in salinized seedlings $(\mathrm{r}=0.79, P<0.001$; Fig. $4 \mathrm{~A})$. In addition, because gravimetric $E_{\mathrm{wp}}$ was correlated to instantaneous $E_{\mathrm{lf}}(\mathrm{r}=0.53, P<0.001)$, relationships between leaf $\mathrm{Cl}^{-}$and $E_{\mathrm{wp}}$ (data not shown) were very similar to those of leaf $\mathrm{Cl}^{-}$versus $E_{1 \mathrm{f}}$. Leaf $\mathrm{Cl}^{-}$decreased with increasing leaf WUE in salinized Carr $(\mathrm{r}=-0.71, P<0.01)$, but the decrease in leaf $\mathrm{Cl}^{-}$with increasing WUE was not significant in salinized Cleo seedlings (Fig. 4B).

Expt. 3: SAlinity And Shade. The shade treatment lowered midday $P A R$ by $59 \%$ during the spring period and by $53 \%$ in the fall relative to the unshaded (sun) treatment (Table 2). Shade also decreased average leaf temperatures more than $2{ }^{\circ} \mathrm{C}$ and leaf-to-air VPD in the spring and fall. The daylength at this location (lat. $28^{\circ} 9^{\prime} \mathrm{N}$ ) was almost $14 \mathrm{~h}$ at the end of the spring salinity period, but only about $11 \mathrm{~h}$ at the end of the fall period. The shade-induced decreases in midday leaf temperature and VPD did not affect 'Valencia' orange tree growth, $\mathrm{Sh} / \mathrm{Rt}$, or $\mathrm{E}_{\mathrm{lf}}$, but salinity stress did reduce leaf growth and $E_{1 \mathrm{f}}$ (García-Sánchez et al., 2006). At the end of the spring period, 'Valencia' orange $E_{1 \mathrm{f}}$ was almost three-fold higher than $E_{1 \mathrm{f}}$ in the fall, regardless of rootstock or salinity treatment (Fig. 5A). In salinized trees, average leaf $\mathrm{Cl}^{-}$was about two-fold higher in the spring than in the fall. Combining all salinized data from the two seasons, leaf $\mathrm{Cl}^{-}$increased with $E_{\text {lf }}$ (r $=0.78, P<0.001)$ regardless of rootstock or shade treatment. In addition, leaf $\mathrm{Cl}^{-}$was also correlated with $E_{1 \mathrm{f}}(\mathrm{r}=0.45, P<0.01)$ in salinized trees in the fall, but not within the higher data from the spring. In salinized trees, leaf $\mathrm{Cl}^{-}$decreased with increasing leaf WUE regardless of rootstock or shade condition during growth (dashed line,

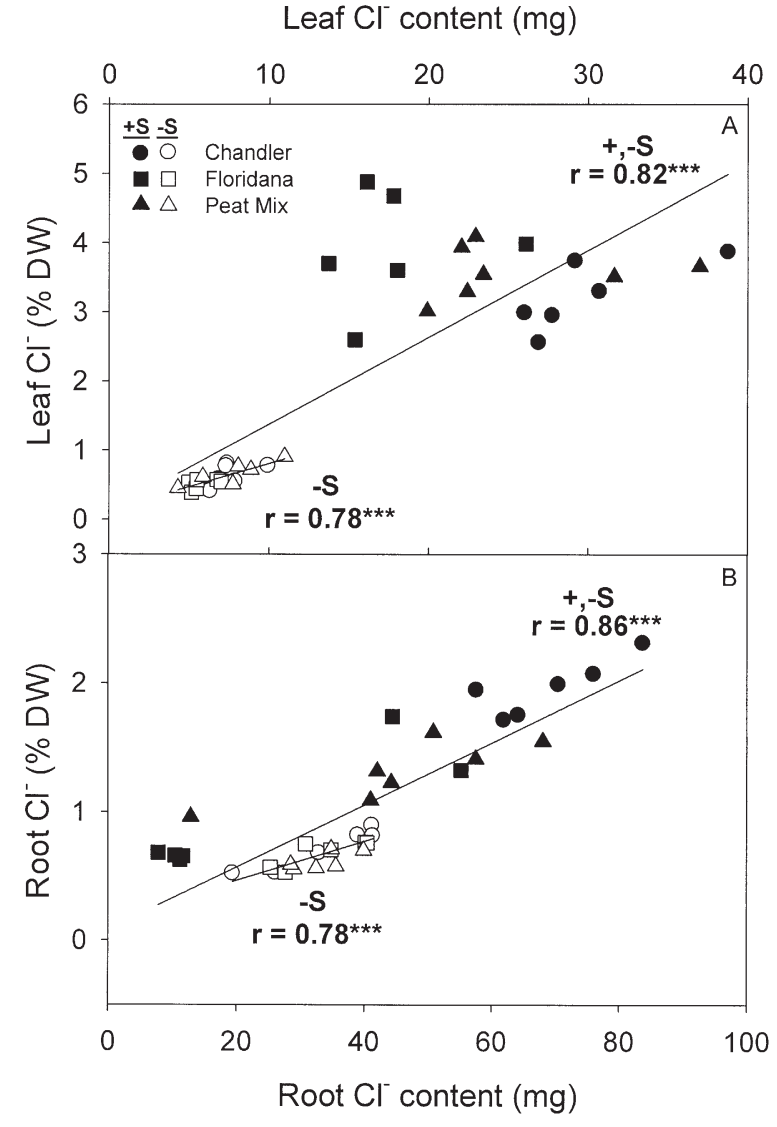

Fig. 2. (Expt. 1) Effects of growing Carrizo citrange seedlings in salinized $[+\mathrm{S}$ (solid symbols)] or non-salinized [-S (open symbols)] Candler sand, Floridana clay soil, or a soilless peat mix on relationships between (A) leaf $\mathrm{Cl}^{-}$concentration and leaf $\mathrm{Cl}^{-}$content and $(\mathbf{B}) \operatorname{root~} \mathrm{Cl}^{-}$concentration and root $\mathrm{Cl}^{-}$content; $* * *=$ correlations coefficients are significant at $P<0.001$.

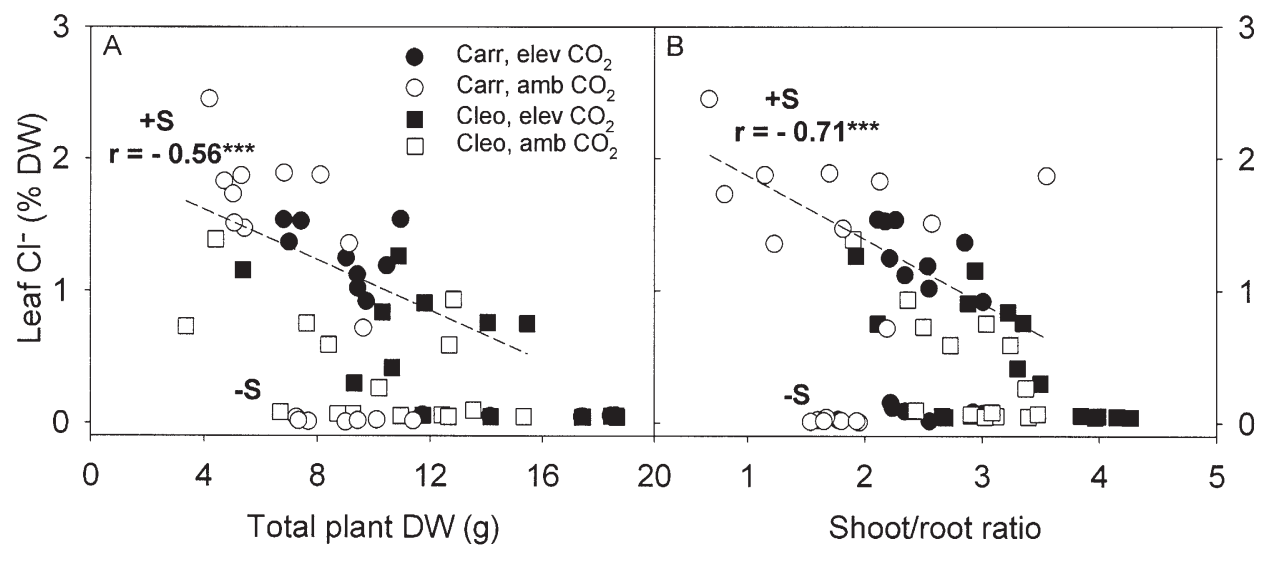

Fig. 3. (Expt. 2) Effects of elevated $\left[\mathrm{elev}=700 \mu \mathrm{L} \cdot \mathrm{L}^{-1}\right.$ (closed symbols) $]$ versus ambient $\mathrm{CO}_{2}\left[\mathrm{amb}=360 \mu \mathrm{L} \cdot \mathrm{L}^{-1}\right.$ (open symbols)] and salinity $(-\mathrm{S}=0 \mathrm{~mm} \mathrm{NaCl},+\mathrm{S}=50 \mathrm{~mm} \mathrm{NaCl})$ on leaf $\mathrm{Cl}^{-}$versus total plant DW (A) and shoot/root ratio (B) of Carrizo citrange [Carr (round symbols)] or Cleopatra mandarin [Cleo (square symbols)] rootstock seedlings. Symbols from the $-\mathrm{S}$ treatments are grouped along the $\mathrm{x}$-axis; $* * *=$ correlations coefficients for the $+\mathrm{S}$ data (dashed line) are significant at $P<0.001$. 


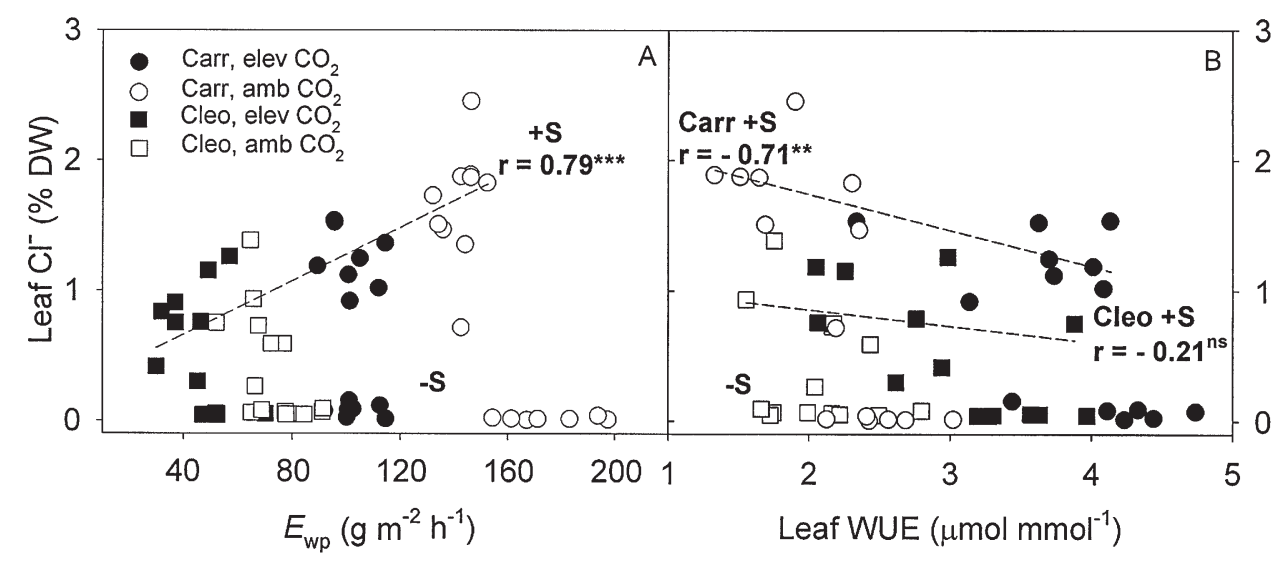

Fig. 4. (Expt. 2) Effects of elevated [elev $=700 \mu \mathrm{L} \cdot \mathrm{L}^{-1}$ (closed symbols] versus ambient $\mathrm{CO}_{2}\left[\mathrm{amb}=360 \mu \mathrm{L} \cdot \mathrm{L}^{-1}\right.$ (open symbols)] and salinity $(-\mathrm{S}=0 \mathrm{~mm} \mathrm{NaCl},+\mathrm{S}=50 \mathrm{~mm} \mathrm{NaCl})$ on leaf $\mathrm{Cl}^{-}$versus whole plant leaf transpiration $\left[E_{\mathrm{wp}}(\mathrm{A})\right]$ and leaf $\mathrm{Cl}^{-}$versus leaf water use efficiency [WUE (B)] of Carrizo citrange [Carr (round symbols)] or Cleopatra mandarin [Cleo (square symbols)] rootstock seedlings. Symbols from the $-\mathrm{S}$ treatments are grouped along the $\mathrm{x}$-axis; $+\mathrm{S}=$ dashed line; $* * *$ or $* *=$ correlations coefficients are significant at $P<0.001$ or 0.01 , respectively.

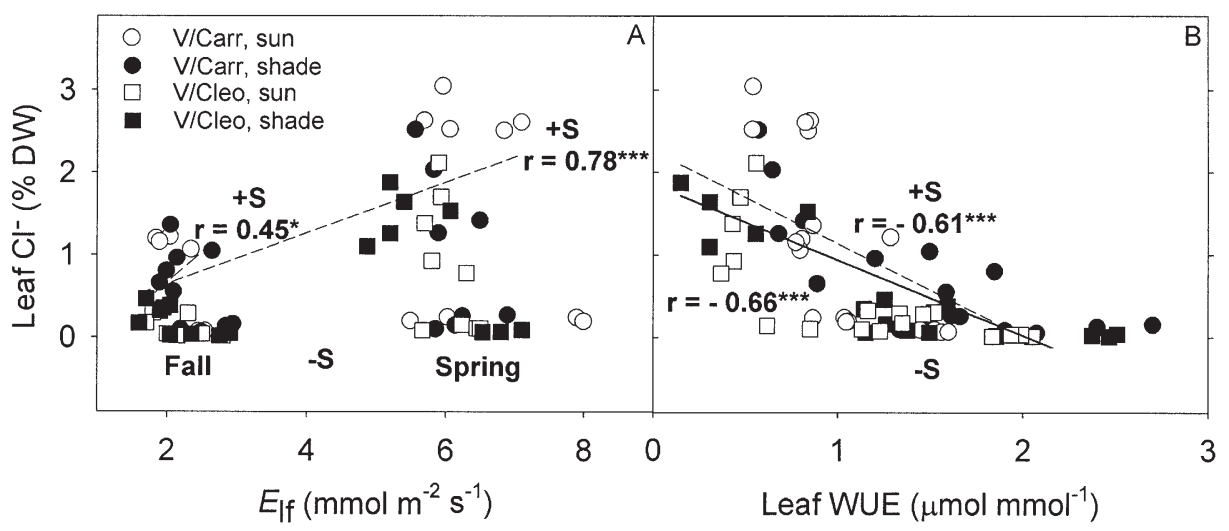

Fig. 5. (Expt. 3) Effects of sun (open symbols) versus shade (closed symbols) and salinity $(-\mathrm{S}=0 \mathrm{~mm} \mathrm{NaCl},+\mathrm{S}=$ $50 \mathrm{~mm} \mathrm{NaCl}$ ) on leaf $\mathrm{Cl}^{-}$versus leaf transpiration $\left[E_{1 \mathrm{f}}(\mathrm{A})\right]$ and leaf $\mathrm{Cl}^{-}$versus leaf water use efficiency [WUE (B)] of 2-year-old 'Valencia' (V) orange trees on Carrizo citrange [Carr (round symbols)] or Cleopatra mandarin [Cleo (square symbols)] rootstocks at the end of the fall spring and salinization periods. Symbols from the $-\mathrm{S}$ treatments are grouped along the $\mathrm{x}$-axis; $+\mathrm{S}=$ dashed line, all data $=$ solid line; $* * *$ or $*=$ correlations coefficients are significant at $P<0.001$ or 0.05 , respectively.

( $\mathrm{r}=0.85, P<0.001)$, and root $\mathrm{Cl}^{-}$concentrations were correlated with total root $\mathrm{Cl}^{-}$contents $(\mathrm{r}=0.74, P<0.001$; data not shown).

\section{Discussion}

Across all treatments within all three experiments, concentrations of $\mathrm{Cl}^{-}$in salinized leaves and roots were strongly correlated with total leaf and root $\mathrm{Cl}^{-}$contents, respectively (see Fig. 2). Thus, the overall negative relationships between tissue $\mathrm{Cl}^{-}$concentrations and growth characteristics in Expts. 1 and 2 appeared similar to relationships with total $\mathrm{Cl}^{-}$accumulation as estimated from tissue $\mathrm{Cl}^{-}$contents (data not shown).

All plants were well-irrigated. Leaf $\mathrm{Cl}^{-}$accumulated with water use because there were positive relationships between leaf $\mathrm{Cl}^{-}$and water use $\left(E_{\mathrm{lf}}\right.$ or $\left.E_{\mathrm{wp}}\right)$ in all three experiments. However, the higher EC and $\mathrm{Cl}^{-}$concentration in the clay soil in Expt. 1 (Table 1) may have resulted in differences in plant water status (García-Sánchez and Syvertsen, 2009) and confounded the leaf $\mathrm{Cl}^{-} / E_{1 f}$ relationship in the salinized Carr seedlings.

In the $\mathrm{eCO}_{2}$ experiment (Expt. 2 ), salinity decreased plant growth, $\mathrm{Sh} / \mathrm{Rt}$, net gas exchange, and water use in both rootstocks seedlings regardless of $\mathrm{CO}_{2}$ level, whereas $\mathrm{eCO}_{2}$ increased growth and $\mathrm{Sh} / \mathrm{Rt}$ (García-Sánchez and Syvertsen, 2006). Elevated $\mathrm{CO}_{2}$ also reduced $E_{1 \mathrm{f}}$ and decreased leaf $\mathrm{Cl}^{-}$concentration in salinized Carr, but not in Cleo. Thus, salinity tolerance was increased by $\mathrm{eCO}_{2}$ in the more saltsensitive Carr, but not in the more salt-tolerant Cleo. This could have been due to the reduced water use and, thus, lower salt ion uptake by $\mathrm{eCO}_{2}$ and/or to the dilution of $\mathrm{Na}^{+}$ and $\mathrm{Cl}^{-}$accumulation by the increased growth in the $\mathrm{eCO}_{2}$. In addition, patterns of $\mathrm{Cl}^{-}$and $\mathrm{Na}^{+}$ responses in roots generally were in the opposite direction to their respec-

2 tive responses in leaves. The modifications of citrus seedling responses

1 to salinity by the higher growth and lower water use at $\mathrm{eCO}_{2}$ were 0 not only species dependent, but also involved whole plant growth and allocations of $\mathrm{Na}^{+}$and $\mathrm{Cl}^{-}$(GarcíaSánchez and Syvertsen, 2006). Although $A_{\mathrm{C}}$ was reduced by salinity stress in both species, the negative correlation between $A_{\mathrm{C}}$ and leaf $\mathrm{Cl}^{-}$ concentration has also been shown to be stronger in Carr than in Cleo (Lopez-Climent et al., 2008). A number of membrane transporter genes that were responsive to $\mathrm{Cl}^{-}$toxicity were also regulated and expressed differently in salt-sensitive Carr than in salt-tolerant Cleo (Brumós et al., 2009).

Some of the variations in leaf area growth of rootstock seedlings could have been attributable to species difference, as the larger Cleo seedlings also have larger entire leaves than the smaller trifoliate Carr seedlings. Leaf $\mathrm{Cl}^{-}$accumulation was positively related to leaf water use, however, as salinized Carr seedlings had higher $E_{\mathrm{wp}}$ and leaf $\mathrm{Cl}^{-}$than Cleo seedlings (Fig. 4). These species differences supported the well-known salinity tolerance differences attributable to these rootstocks even when grown as seedlings (Levy and Syvertsen, 2004). Nonetheless, across both rootstocks and $\mathrm{CO}_{2}$ levels, leaf $\mathrm{Cl}^{-}$was positively related to $E_{\mathrm{wp}}$.

Because leaf $\mathrm{Cl}^{-}$decreased with increased growth and $\mathrm{Sh} / \mathrm{Rt}$, but leaf $\mathrm{Cl}^{-}$increased with $E_{\mathrm{wp}}$, it follows that leaf $\mathrm{Cl}^{-}$should decrease with increased growth per water use (Ball and Munns, 1992). Leaf WUE was higher in Carr than Cleo and WUE was reduced by salinity but increased by $\mathrm{eCO}_{2}$ (García-Sánchez and Syvertsen, 2006). Overall, leaf $\mathrm{Cl}^{-}$was negatively related to 
WUE in salinized seedlings (Fig. 4). To the extent that leaf WUE can be used as a surrogate for whole plant growth or yield per water use, increased leaf WUE under salinity stress can be an indicator of tolerance to salinity. This is an important result as it shows that variations in leaf WUE, a potential integrator of growth and water use, can be used as an index of salt tolerance based on $\mathrm{Cl}^{-}$accumulation in citrus.

The regulation of leaf $\mathrm{Cl}^{-}$concentration in citrus leaves has been associated with $E_{1 \mathrm{f}}$, total water absorbed per plant (Moya et al., 1999, 2003), Sh/Rt, and the efficiency of the root system for limiting the $\mathrm{Cl}^{-}$uptake (Storey and Walker, 1999). The higher exclusion of $\mathrm{Cl}^{-}$from shoots of trees on Cleo than on Carr was also related to the ability of roots to restrict the movement of $\mathrm{Cl}^{-}$because their Sh/Rt, leaf DW, and $E_{\text {lf }}$ were similar (García-Sánchez et al., 2006). Citrus leaves growing in full sun experience high temperatures that decreased midday $A_{\mathrm{C}}$, stomatal conductance $\left(g_{\mathrm{s}}\right)$, and WUE. Lowered leaf temperature from shading increased midday $A_{\mathrm{C}}, g_{\mathrm{s}}$, and leaf WUE but did not affect $E_{1 \mathrm{f}}$. Nonetheless, seasonal variations in $E_{\mathrm{lf}}$ were related to variations in leaf $\mathrm{Cl}^{-}$concentrations in salinized 'Valencia' orange trees regardless of rootstock or shade treatment (Fig. 5). This is remarkable because such seasonal differences in instantaneously measured $E_{\text {lf }}$ by gas exchange would be exaggerated if integrated over the longer days in the spring than in the fall. In addition, at the end of the fall salinization period, there were variations in $E_{\mathrm{lf}}$ that were attributable to differences in rootstock, but independent of shade. Leaves on trees with higher transpiration rates over the longer daylengths in the spring also had higher concentrations of leaf $\mathrm{Cl}^{-}$. There was a negative relationship between leaf $\mathrm{Cl}^{-}$and leaf WUE, again supporting the idea that increased leaf WUE under salinity stress can be an indicator of salt tolerance. These data, therefore, support our original hypothesis that high growth, low water use, and, consequently, high WUE of salinized citrus can result in low leaf $\mathrm{Cl}^{-}$and high salinity tolerance.

There have been many similar reports of physiological responses to salinity in trees and crop plants (Yeo and Flowers, 1989) and even reports underscoring the importance of WUE contributing to salt tolerance (Ball and Munns, 1992). However, this is the first study that summarizes the use of soil type, elevated $\mathrm{CO}_{2}$, and shade to modify growth and water use of salinized citrus and to link high WUE with low $\mathrm{Cl}^{-}$accumulation and salinity tolerance.

Although higher salinities over longer durations may have elicited different responses, it is clear that salinity stress from $50 \mathrm{~mm} \mathrm{NaCl}$ for 8 to 9 weeks reduced growth and water use in well-irrigated citrus seedlings and grafted trees. Growth reductions by salinity were greater in the more salt-sensitive Carr seedlings and in 'Valencia' orange trees grafted on Carr rootstock than for Cleo seedlings and trees on Cleo, which was related to leaf $\mathrm{Cl}^{-}$concentrations (García-Sánchez et al., 2006). Such different effects of salinity on growth and leaf $\mathrm{Cl}^{-}$between Cleo and Carr were consistent with earlier findings (GarcíaSánchez et al., 2002) and underscore the importance of whole plant growth and salt ion allocation between root and shoots. Regardless of whether substrate type, $\mathrm{eCO}_{2}$, or shade modified growth and water use of salinized Carr or Cleo seedlings or of grafted 'Valencia' orange trees on these contrasting rootstocks, leaf $\mathrm{Cl}^{-}$accumulation was positively related to water use and negatively related to growth, $\mathrm{Sh} / \mathrm{Rt}$, and WUE. Thus, based on $\mathrm{Cl}^{-}$accumulation, the ability to maintain high WUE under salinity stress can be an important indicator of salt tolerance.

\section{Literature Cited}

Ball, M.C. and R. Munns. 1992. Plant responses to salinity under elevated atmospheric concentrations of $\mathrm{CO}_{2}$. Aust. J. Bot. 40:515-525. Bañuls, J., M.D. Serna, F. Legaz, M. Talón, and E. Primo-Millo. 1997. Growth and gas exchange parameters and water relations of citrus plants stressed with different salts. J. Plant Physiol. 150:194-199.

Bowes, G. 1991. Growth at elevated $\mathrm{CO}_{2}$ : Photosynthesis responses mediated through Rubisco. Plant Cell Environ. 14:795-806.

Brumós, J., J.M. Colmenero-Flores, A. Conesa, P. Izquierdo, G. Sánchez, D.J. Iglesias, M.F. López-Climent, A. Gómez-Cadenas, and M. Talón. 2009. Membrane transporters and carbon metabolism implicated in chloride homeostasis differentiate salt stress responses in tolerant and sensitive Citrus rootstocks. Funct. Integr. Genomics 9:293-309.

Castle, W.S. and A.H. Krezdorn. 1975. Effect of citrus rootstocks on root distribution and leaf mineral content of Orlando tangelo trees. J. Amer. Soc. Hort. Sci. 100:1-4.

Castle, W.S., D.P.H. Tucker, A.H. Krezdorn, and C.O. Youtsey. 1993. Rootstocks for Florida citrus. 2nd ed. Univ. Florida, Inst. Food Agr. Sci., SP-42.

Chen, K. and F. Lenz. 1997. Responses of strawberry to doubled $\mathrm{CO}_{2}$ concentration and phosphorus deficiency. II. Gas exchange and water consumption. Gartenbauwissenchaft 62:90-96.

Flowers, T.J. and S.A. Flowers. 2005. Why does salinity pose such a difficult problem for plant breeders? Agr. Water Mgt. 78:15-24.

García-Sánchez, F. and J.P. Syvertsen. 2006. Salinity tolerance of Cleopatra mandarin and Carrizo citrange citrus rootstock seedling is affected by $\mathrm{CO}_{2}$ enrichment during growth. J. Amer. Soc. Hort. Sci. 131:24-31.

García-Sánchez, F.G. and J.P. Syvertsen. 2009. Substrate type and salinity affect growth allocation, tissue ion concentrations and physiological responses of Carrizo citrange seedlings. HortScience 44:1432-1437.

García-Sánchez, F., J. Jifon, M. Carvajal, and J.P. Syvertsen. 2002. Gas exchange, chlorophyll and nutrient contents in relation to $\mathrm{Na}^{+}$ and $\mathrm{Cl}^{-}$accumulation in 'Sunburst' mandarin grafted on different rootstock. Plant Sci. 162:705-712.

García-Sánchez, F., J.P. Syvertsen, V. Martínez, and J.C. Melgar. 2006. Salinity tolerance of 'Valencia' orange trees grafted on contrasting rootstocks is not improved by moderate shade. J. Expt. Bot. 57:3697-3706.

Hu, M.-J., Y.-P. Guo, Y.-G. Shen, D.-P. Guo, and D.-Y. Li. 2009. Midday depression of photosynthesis and effects of mist spray in citrus. Ann. Appl. Biol. 154:143-155.

Jifon, J.L. and J.P. Syvertsen. 2003a. Moderate shade can increase net gas exchange and reduce photoinhibition in citrus leaves. Tree Physiol. 23:119-127.

Jifon, J.L. and J.P. Syvertsen. 2003b. Kaolin particle film applications can increase photosynthesis and water use efficiency of 'Ruby red' grapefruit leaves. J. Amer. Soc. Hort. Sci. 128:107-112.

Levy, Y. and J.P. Syvertsen. 2004. Irrigation water quality and salinity effects in citrus trees. Hort. Rev. (Amer. Soc. Hort. Sci.) 30:37-82.

Lopez-Climent, M.F., V. Arbona, R.M. Perez-Clemente, and A. Gomez-Cadenas. 2008. Relationship between salt tolerance and photosynthetic machinery performance in citrus. Environ. Exp. Bot. 62:176-184.

Maas, E.V. 1993. Salinity and citriculture. Tree Physiol. 12:195-216. Moya, J.L., A. Gómez-Cadenas, E. Primo-Millo, and M. Talón. 2003. Chloride absorption in salt-sensitive Carrizo citrange and salttolerant Cleopatra mandarin citrus rootstocks is linked to water use. J. Expt. Bot. 54:825-833.

Moya, J.L., E. Primo-Millo, and M. Talón. 1999. Morphological factors determining salt tolerant in citrus seedlings: The shoot to root ratio modulates passive root uptake of chloride ions and their accumulation in leaves. Plant Cell Environ. 22:1425-1433.

Munns, R. and R.A. James. 2003. Screening methods for salinity tolerance: A case study with tetraploid wheat. Plant Soil 253:201-218. 
Pérez-Pérez, J.G., J.P. Syvertsen, P. Botía, and F. García-Sánchez. 2007. Leaf water relations and net gas exchange responses of salinized Carrizo citrange seedlings during drought stress and recovery. Ann. Bot. (Lond.) 100:335-345.

Storey, R. and R.R. Walker. 1999. Citrus and salinity. Scientia Hort. 78:39-81.

Syvertsen, J.P., B. Boman, and D.P.H. Tucker. 1989. Salinity in Florida citrus production. Proc. Florida State Hort. Soc. 102:61-64. Syvertsen, J.P., C. Goñi, and A. Otero. 2003. Fruit load and canopy shading affect leaf characteristics and net gas exchange of 'Spring' navel orange trees. Tree Physiol. 23:899-906.
Tattini, M., D. Remorini, P. Pinelli, G. Agati, E. Saracini, M.L. Traversi, and R. Massai. 2006. Morpho-anatomical, physiological and biochemical adjustments in response to root zone salinity stress and high solar radiation in two Mediterranean evergreen shrubs, Myrtus communis and Pistacia lentiscus. New Phytol. 170:779-794.

Yeo, A.R. and T.J. Flowers. 1989. Selection for physiological characteristics: Examples of breeding for salt tolerance, p. 217234. In: H.G. Jones, T.J. Flowers, and M.B. Jones (eds.). Plants under stress. Soc. Expt. Biol., Seminar Ser. 39. Cambridge University Press, Cambridge, UK. 